\title{
A Review on the Urease Inhibition Potential of Various Compounds
}

\author{
Parvinder, Saloni Kakkar ${ }^{*}$, Anurag Khatkar ${ }^{*}$ \\ Faculty of Pharmaceutical Sciences, M.D. University, Rohtak, India-124001
}

Address for Correspondence: Saloni Kakkar, salonikakkar2007@gmail.com ; Anurag Khatkar, anuragpharmacy@gmail.com

\begin{abstract}
Received:
22.07.2018

Accepted:

05.02.2019

Keywords

Urease; Urease

inhibitors; Gallic

acid derivatives.

ABSTRACT: Urease is a nickel containing metalloenzyme which is found in many bacteria, fungi, algae, plants, soil and some invertibrates. Urease catalyzes the hydrolysis of urea causing a $\mathrm{pH}$ increase of its environment which may be noxious for human tissues and causes many serious disorders/diseases. In this context, a number of natural and synthetic urease inhibitors were reviewed. There are a number of gallic acid derivatives which have different pharmacological activities reviewed from the literature. (c) 2019 iGlobal Research and Publishing Foundation. All rights reserved.
\end{abstract}

Cite this article as: Parvinder; Kakkar, S.; Khatkar, A. A review on the urease inhibition potential of various compounds. Indo Global J. Pharm. Sci., 2019; 9(1): 42-53. DOI: http://doi.org/10.35652/IGJPS.2019.9106.

\section{INTRODUCTION}

Urease (EC 3.5.1.5) is a nickel containing metalloenzyme of high molecular weight [1] belonging to the superfamily of amidohydrolases and phosphotriesterases [2]. Urease was the first crystallized enzymatic protein [3] which is found in many bacteria [1], fungi [4], algae, plants [5] and some invertibrates [6] as well as in soil, as a soil enzyme. It is widely distributed in soil, water, human and animal body [1].

Urease catalyzes the hydrolysis of urea $\sim 10^{15}$ times superior than the rate of uncatalyzed reaction [7] in which it produces ammonia and carbonic acid causing a $\mathrm{pH}$ increase of its environment [8]. Excess production of ammonia via urea hydrolysis, may be noxious for human tissues $[9,10]$ and causes many serious disorders/diseases which include urinary stones occurrence and catheters blocking, pyelonephritis, ammonia and hepatic encephalopathy, hepatic coma [11,12] rheumatoid arthritis or atherosclerosis as well as cardiovascular disease [13]. Urease also contributes in the ecological cycling of a variety of nitrogen compounds, in addition to urea based fertilizers. In disparity to the pathogenic property of microbial ureases, these are significant enzymes in ruminant metabolism and in ecological conversions of definite nitrogenous compounds [1]. It is found in human sera as an immunogenic protein and acts as antibodies. Urease is also used for diagnostic purposes in the diagnosis of several bacteria like Helicobacter pylori [14,15]. Helicobacter pylori get benefits of the increase in $\mathrm{pH}$ to stay alive in the acidic environment of the host's stomach, as a result causes stomach ulcers, after a while leading to cancer [16,17].

From a very long time natural products are used as a source of medicines [18]. Amongst wide range of natural products phenolic acids are compounds of huge importance having broad range of biological activities [19]. Phenolic acids belong to non-flavonoid family having large number of phenolic compounds [20] which get absorbed rapidly after oral, parentral administration [21]. Among all the phenolic acid contents gallic acid is a compound of great interest as it possesses a number of biological activities like antioxidant [22], antimicrobial [23], anti-inflammatory [24], antitumour [25] and antidiabetic [26].

Gallic acid is a trihydroxybenzoic acid, also known as 3,4,5trihydroxybenzoic acid. It occurs as a white, yellowish-white, or pale fawn-colored crystals having molar mass - 170.12 $\mathrm{g} / \mathrm{mol}$ and molecular formula $\mathrm{C}_{7} \mathrm{H}_{6} \mathrm{O}_{5}$. It is obtained from 
Indo Global Journal of Pharmaceutical Sciences, 2019; 9(1): 42-53

gallnuts, sumac, witch hazel, tea leaves, oak bark, and some other plants [25].

\section{INHIBITORS OF UREASE ENZYME}

Implications of the urease are mounting in the developing countries, while in some parts of the world more than $50 \%$ of the population is reported to be infected with helicobacter

\begin{tabular}{|c|c|c|c|c|c|}
\hline S.No. & Source & $\begin{array}{l}\text { Family/ } \\
\text { Category }\end{array}$ & Part used/ Phytoconstituents & Model & References \\
\hline 1. & Artemisia scoparia & Asteraceae & Shoot extracts & Canavalia ensiformis & [29] \\
\hline 2. & Rheum ribes & Polygonaceae & Root extracts & - & {$[30]$} \\
\hline 3. & Sambucus ebulus & Adoxaceae & Fruit extracts & - & [30] \\
\hline 4. & Camelia sinensis & Thaceae & Leaf extracts & Helicobacter Pylori & {$[31]$} \\
\hline 5 & Matricaria recutita & Asteraceae & Flower extracts & Helicobacter Pylori & {$[31]$} \\
\hline 6. & Fagonia arabica & Zygophyllaceae & Whole plant extracts & Helicobacter Pylori & {$[32]$} \\
\hline 7. & Lonicera japonica & Caprifoliaceae & Flower extracts & Helicobacter Pylori & [33] \\
\hline 8. & Brassica oleraceae & Brassicaceae & Cabbage juice & Jack bean urease & [34] \\
\hline 9. & Vernonia cinerascens & Terpenoids & $\begin{array}{l}\text { Root extracts (Vernonione } 3 \beta \text {-acetoxy- } 5 \alpha \text { - } \\
\text { angeloyloxy- } 7 \text {-deoxy-carvotacetone) }\end{array}$ & Jack bean urease & {$[35]$} \\
\hline 10. & Plumeria rubra & Terpenoids & $\begin{array}{l}\text { Plant extracts (Rubrajaleelol \& } \\
\text { Rubrajaleelic acid) }\end{array}$ & Human urease & [36] \\
\hline 11. & $\begin{array}{l}\text { Zygophyllum fabago } \\
\text { linn }\end{array}$ & Terpenoids & Ariel part (Zygofaboside A) & Bacillus pasteurii & [29] \\
\hline 12. & $\begin{array}{l}\text { Stereospermum } \\
\text { acuminatissimum } k . \\
\text { schum }\end{array}$ & Phenols & Stem (Syringaldehyde) & Jack bean urease & {$[37]$} \\
\hline 13. & Paeonia lactiflora & Phenolic acids & $\begin{array}{l}\text { Root extracts (Methyl gallate \& 1,2,3,4,6- } \\
\text { Penta-o-galloyl- } \beta \text {-D-glucopyranose) }\end{array}$ & Helicobacter Pylori & {$[38]$} \\
\hline 14. & $\begin{array}{l}\text { Stereospermumacumin } \\
\text { atissimum k. schum }\end{array}$ & Phenolic acids & Stem bark (Atranorin \& Ellagic acid) & Jack bean urease & {$[37]$} \\
\hline 15. & Mallotus philippensis & Phenolic acids & Bark extracts (Bergenin) & Bacillus pasteurii & [39] \\
\hline 16. & Daphne retusa & $\begin{array}{l}\text { Flavones \& their } \\
\text { glycosides }\end{array}$ & Plant extracts (5,7-Dihydroxyflavone) & Jack bean urease & [40] \\
\hline 17. & $\begin{array}{l}\text { Scutellaria } \\
\text { glucuronide }\end{array}$ & $\begin{array}{l}\text { Flavones O- } \\
\text { glycosides }\end{array}$ & Root extracts (Baicalin) & Jack bean urease & [41] \\
\hline 18. & Erigeron breviscapus & $\begin{array}{l}\text { Flavones O- } \\
\text { glycosides }\end{array}$ & Scutellarin & Jack bean urease & {$[42]$} \\
\hline 19. & $\begin{array}{l}\text { Hypericum } \\
\text { oblongifolium }\end{array}$ & Xanthones & $\begin{array}{l}\text { Root extract (Hypericorin C and 1,2- } \\
\text { Dihydroxy-8-methoxyxanthone) }\end{array}$ & Jack bean urease & [43] \\
\hline 20. & Corydalis govaniana & Alkaloids & $\begin{array}{l}\text { Plant extract } \\
\text { (Govaniadine,Caseadine,Caseamine and } \\
\text { Protopine) }\end{array}$ & Jack bean urease & {$[44]$} \\
\hline 21. & Lawsonia alba lam & Quinones & $\begin{array}{l}\text { Stem extract (2-( } \beta \text {-D-glucopyranosyloxy)- } \\
\text { 1,4-naphthoquinone }\end{array}$ & Jack bean urease & {$[45]$} \\
\hline 22. & Viola betonicifolia & Quinones & Plant extract (3-Methoxydalbergione) & Bacillus pasteurii & [46] \\
\hline 23. & Pityriasis rubra & Iridoids & Rubradoid,Plumieride p-z-coumarate & Human urease & [36] \\
\hline 24. & Pityriasis rubra & Sphingolipids & Rubranin & Human urease & [36] \\
\hline 25. & Indigofera gerardiana & Phenols & $\begin{array}{l}\text { Plant extracts (Indigoferin-B \& } \\
\text { Indigoferin-C) }\end{array}$ & Jack bean urease & {$[47]$} \\
\hline 26. & Vernonia cinerascens & Phenols & $\begin{array}{l}\text { Herb extracts (2-Hydroxy-3-methoxy-5-(2- } \\
\text { propenyl)-phenol) }\end{array}$ & Jack bean urease & {$[35]$} \\
\hline 27. & Vitis vinifera & Stilbenes & Resveratrol & Helicobacter Pylori & [48] \\
\hline 28. & Celtis africana & $\begin{array}{l}\text { Flavones C- } \\
\text { glycosides }\end{array}$ & Vitexin,Orientin \& Isoswertisin & Jack bean urease & [49] \\
\hline
\end{tabular}

Table 1: Natural Inhibitors of urease enzyme pylori [27]. Due to the assorted functions of urease enzyme, its inhibition by potent and specific compounds could lead to the treatment of infections caused by urease-producing bacteria [28]. There are many reported natural urease inhibitors which are given in (Table 1): 
Indo Global Journal of Pharmaceutical Sciences, 2019; 9(1): 42-53

Synthetic urease inhibitors contain (Table-2):

\begin{tabular}{|c|c|c|c|}
\hline Sr. No. & Chemical constituents & Model & References \\
\hline 1. & 3,4,5-Trihydroxybenzohydrazone & Jack bean urease & {$[50]$} \\
\hline 2. & $\begin{array}{l}\text { Carbazole substituted pyrimidine } \\
\text { derivatives }\end{array}$ & Jack bean urease & [51] \\
\hline 3. & Barbituric acid derivatives & Jack bean urease & [52] \\
\hline 4. & 2,5-Substituted-1,4-benzoquinone & Helicobacter Pylori & [53] \\
\hline 5. & Hydroxamic acids & Helicobacter Pylori & [54] \\
\hline 6. & $\begin{array}{l}\text { Isatin derived bis-schiff bases and their } \\
\text { copper complexes }\end{array}$ & Jack bean urease & [55] \\
\hline 7. & 1,3,4-Oxadiazole derivatives & Jack bean urease & [56] \\
\hline 8. & $\begin{array}{l}\text { Substituted aminomethane p- } \\
\text { hydroxymethyl-phosphonic acids }\end{array}$ & & [57] \\
\hline 9. & 5,6-Dihydropyridine derivatives & Jack bean urease & [58] \\
\hline 10. & $\mathrm{~N}$-analogs of 1,2-diarylethane & Helicobacter Pylori & [59] \\
\hline 11. & $\begin{array}{l}\text { 3-Arylpropionylhydroxamic acid } \\
\text { derivatives }\end{array}$ & Helicobacter Pylori & [60] \\
\hline 12. & 1,2-Benzisoselenazol-3-one derivatives & $\begin{array}{l}\text { Sporosarcina Pasteurii and } \\
\text { Helicobacter Pylori }\end{array}$ & [61] \\
\hline 13. & $\begin{array}{l}\beta \text {-Hydroxy- } \beta \text {-phenylpropionyl-hydroxamic } \\
\text { acid }\end{array}$ & Helicobacter Pylori & [33] \\
\hline 14. & 2-Methoxybenzoylhydrazones & - & [62] \\
\hline 15. & Oxindole derivatives & - & [63] \\
\hline 16. & Benzothiazole derivatives & Helicobacter Pylori & [64] \\
\hline
\end{tabular}

Table 2: Synthetic Inhibitors of urease enzyme

Pharmacological activities of gallic acid derivatives (Table-3):

\begin{tabular}{|c|c|c|c|}
\hline $\begin{array}{l}\text { Sr. } \\
\text { No. }\end{array}$ & Chemical constituents & Biological activity & References \\
\hline 1. & $\begin{array}{l}4 \text { Medicinal plant extracts [guava (Psidium guajava) leaf, capillary } \\
\text { wormwood (Artemisia capillaries Thunb.), Chinese goldthread } \\
\text { (Coptis chinensis), and dandelion (Taraxacum platycarpum)] }\end{array}$ & Anti-inflammatory & [24] \\
\hline 2. & Gallic acid based steroidal phenstatin analogues & Anticancer & [25] \\
\hline 3. & $\begin{array}{l}\text { Gallic acid purified from Terminalia nigrovenulosa bark against } \\
\text { Fusarium solani }\end{array}$ & Antifungal & [12] \\
\hline 4. & $\begin{array}{l}\text { A bioactive derivative of chitooligosaccharides was synthesized via } \\
\text { grafting of gallic acid onto chitooligosaccharides (G-COS) }\end{array}$ & Antiallergic & [65] \\
\hline 5. & $\begin{array}{l}\text { Gallic acid and catechin against Helicobacter pylori by an agar- } \\
\text { well diffusion method }\end{array}$ & Antimicrobial & [23] \\
\hline 6. & $\begin{array}{l}\text { 3,4,5-Trihydroxybenzoic acid, a major bioactive polyphenol present } \\
\text { in Cyamopsis tetragonoloba, exhibited antihyperglycemic activity. }\end{array}$ & Antidiabetic & [26] \\
\hline 7. & Ellagic acid & Antioxidant & [22] \\
\hline 8. & Chitosan-gallic acid films by the log reduction method & Antimicrobial & [66] \\
\hline 9. & Quinolin-8-yl 3,4,5-trihydroxybenzoate & Antimicrobial & [67] \\
\hline
\end{tabular}

Table 3: Different pharmacological activities of gallic acid derivatives 
Indo Global Journal of Pharmaceutical Sciences, 2019; 9(1): 42-53

BIOLOGICAL PROFILE OF UREASE

\section{INHIBITORS}

Saify et al., studied the synthesis of (1H-pyrrolo [2,3-b] pyridine) 7-azaindole derivatives and screened for their urease, phosphodiesterase and beta-glucuronidase inhibitory activity. Urease inhibitory activity was measured by using the indophenols method. Beta-glucuronidase inhibitory activity was measured by using the spectrophotmetric method. Phosphodiesterase inhibitory activity was determined by using the lysophospholipids. Out of all 7-azaindole derivatives, compound 7-[2-(4-methoxy-phenyl)-2-oxo-ethyl]-1Hpyrrolo[2,3-b]pyridine-7-ium (1) with $\mathrm{IC}_{50}=2.19 \pm 0.37 \mu \mathrm{M}$ was found to be highly active against jack bean urease as compared with reference drug thiourea $\left(\mathrm{IC}_{50}=21.00 \pm 0.01 \mu \mathrm{M}\right)$ [68].<smiles>Cc1ccc(C(=O)C[N+]2=CC=CC3C=CNC32)cc1</smiles>

(1)

Ziarani et al., synthesized the pyrano (2,3-d)-pyrimidine dione derivatives facilitated by sulfonic acid nanoporous silica (SBA-Pr- $\left.\mathrm{SO}_{3} \mathrm{H}\right)$ as a nanocatalyst. These derivatives were screened for their urease inhibitory potential using the indophenols method. Binding free energies of the pyrano $(2,3-d)$-pyrimidine derivatives revealed that out of all derivatives, 7-amino-5-(2,4-dichlorophenyl)-2,4-dioxo2,3,4,5-tetrahydro- $1 H$-pyrano [2,3- $d$ ] pyridine-6-carbonitirile (2) was found to be most active with $\mathrm{IC}_{50}=19.45 \mu \mathrm{M}$, when compared with standard drug thiourea with $\mathrm{IC}_{50}=21 \mu \mathrm{M}$ [69].<smiles>N#CC1=C(N)Oc2[nH]c(=O)[nH]c(=O)c2C1c1ccc(Cl)cc1Cl</smiles>

(2)

Khan et al., synthesized the benzophenone hydrazone derivatives and screened for them antioxidant and urease inhibition activities. Antioxidant activity of synthesized compounds was determined by using the 1,1-diphenyl-2- picrylhydrazyl (DPPH) mehod. Urease inhibition activity was measured by using the indophenol method. Studies revealed that 2,4,6-trihydroxy substituted (3) and 2,6-dihydroxy substituted (4) derivatives showed potent activity against jack bean urease with $\mathrm{IC}_{50}=36.36 \pm 0.94 \mu \mathrm{M}$, and $55.5 \pm 0.69 \mu \mathrm{M}$ respectively as compared with standard drug thiourea with $\mathrm{IC}_{50}=21 \pm 0.11 \mu \mathrm{M}[70]$.<smiles>Oc1cc(O)c(/C=N/N=C(c2ccccc2)c2ccccc2)c(O)c1</smiles>

(3)<smiles>C/C(=N\N=C(c1ccccc1)c1ccccc1)c1c(O)cccc1O</smiles>

(4)
Ahmed et al., studied the methanolic extract and sub-fractions in different solvents of Melilotus indicus (Linn.) All., these extracts or fractions were evaluated for $\alpha$-amylase and urease inhibition activities. Urease inhibition potential was measured by using the Indophenols method. Studies revealed that chloroform fraction showed the potent activity with $\mathrm{IC}_{50}=0.89 \mu \mathrm{M}$ against jack bean urease compared with positive control thiourea with $\mathrm{IC}_{50}=0.97 \mu \mathrm{M}$ [71].

Golbabaei et al., studied the four $\beta$-boswilic acid derivatives isolated from Baswellia carterii. These compounds were charaacterised by NMR and Mass spectroscopic techniques and were screened for their urease inhibitory potential. Docking and pharmacophore analysis were performed by using Autodock 4.2 and ligandscout 3.03 programs to measure the possible interaction between isolated compounds and urease enzyme. Urease inhibition activity was determined by using the indophenols method. Studies revealed that compound

(3R,4R,4aR,6aS,6bS,8aR,11R,12S,12aR,14aS,14bS)-3-

acetoxy-14,14-diethyl 4,4a,6a,6b,8a,11,12,12a,14a,14bdecamethyl-

1,2,3,4,4a,5,6,6a,7,8,8a,9,10,11,12,12a,14,14a,14b-

icosahydropicene-4-carboxylic acid (5) showed the potent activity with $\mathrm{IC}_{50}=6.27 \pm 0.03 \mu \mathrm{M}$, when compared with the positive control thiourea with $\mathrm{IC}_{50}=21.1 \pm 0.3 \mu \mathrm{M}$ against jack bean urease [72].

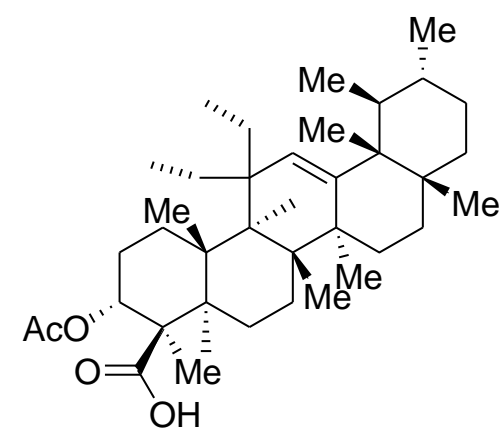

(5) 


\section{Indo Global Journal of Pharmaceutical Sciences, 2019; 9(1): 42-53}

Jamil et al., synthesized a number of $\mathrm{N}^{3}, \mathrm{~N}^{3}$-bis(disubstituted) isophthalyl-bis-(thioureas) derivatives and characterized by using the elemental analysis, infrared and ${ }^{1} \mathrm{H}$ NMR spectroscopy. The synthesized compounds were evaluated for antibacterial and antiurease activities. Antibacterial potential was measured by using the disc diffusion method against some Gram positive and Gram negative bacteria. Urease inhibition activity was measured by using the indophenol method. Studies revealed that out of all bis-thiourea derivatives compounds $\mathrm{N}^{3}, \mathrm{~N}^{3}$-bis-(4carboxyphenyl)isophthalyl-bis-(thiourea) (6), $\mathrm{N}^{3}, \mathrm{~N}^{3}$ - bis-(3nitrophenyl)isophthalyl-bis-(thiourea) (7), showed potent activity, exhibiting $\mathrm{IC}_{50}=26.3 \pm 0.5 \mu \mathrm{M}$ and $26.7 \pm 0.5 \mu \mathrm{M}$ against jack bean urease compared with thiourea $\mathrm{IC}_{50}=21.1 \pm$ $0.1 \mu \mathrm{M}$. It was also found that some derivatives had potent anti-bacterial activity [73].

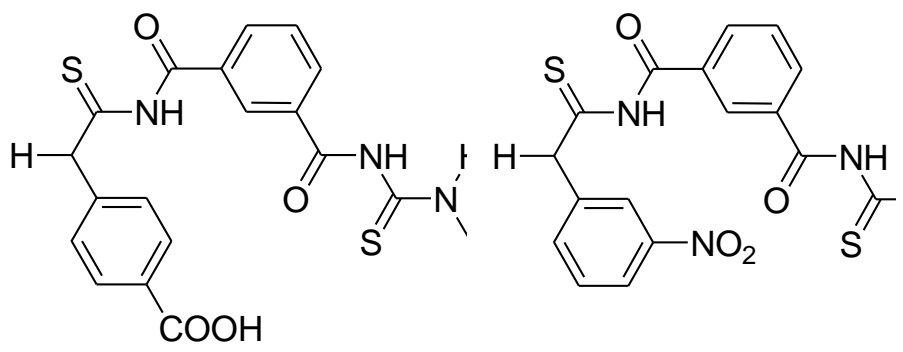

(6)

(7)

Ullah et al., evaluated the urease inhibitory capacity of extract/fractions and isolated compounds of Monotheca buxifolia fruit. Urease inhibiting activity was determined by using the indophinol method and their molecular docking studies. Out of all extract/fractions, ethyl acetate fraction showed the maximum inhibition of $61.7 \%$ compared with thiourea $98.2 \%$ and from isolated compounds isoquercetin (8) exhibiting $\mathrm{IC}_{50}=51.6 \pm 1.46 \mu \mathrm{M}$ showed maximum potential when compared with thiourea exhibiting $\mathrm{IC}_{50}=21 \pm 0.11 \mu \mathrm{M}$ against jack bean urease. After evaluated the compounds it was proved that Monotheca buxifolia fruit was very useful in gastritis and urinary tract infections [74].<smiles>O=c1c(OC2OC(CO)C(O)C(O)C2O)c(-c2ccc(O)c(O)c2)oc2cc(O)cc(O)c12</smiles>

(8)
Ahmed et al., studied the phenolic content, urease and $\alpha$ amylase inhibitory potentials of methanolic extracts of Rumex acetosella roots and its fractions in different solvents. The methanolic extract and its fractions in chloroform, ethyl acetate, n-butanol and water were evaluated for their urease and $\alpha$-amylase inhibitory activities. Total phenolic content was determined by using the Folin-ciocalten calorimetric method. $\alpha$-amylase inhibitory potential was measured in comparison with the positive control acarbose. Urease inhibitory potential was determined by using the indophenols method. Studies revealed that aqueous fraction of methanolic extract of Rumex acetosella roots showed potent activity i.e. $97.36 \pm 0.13 \%$ inhibition at $20 \mu \mathrm{g} / \mathrm{ml}$ against jack bean urease when compared with standard drug thiourea which showed $95.03 \pm 3.94 \%$ inhibition at $20 \mu \mathrm{g} / \mathrm{ml}[75]$.

\begin{tabular}{|c|c|c|}
\hline Sr. No. & Extracts/Fraction & $\mathrm{IC}_{50}(\mu \mathrm{g} / \mathrm{ml})$ \\
\hline 1. & $\begin{array}{c}\text { Crude methanolic } \\
\text { extracts }\end{array}$ & 0.99 \\
\hline 2. & Chloroform & 3.89 \\
\hline 3. & Ethyl acetate & 1.76 \\
\hline 4. & n-Butanol & 0.91 \\
\hline 5. & Aqueous & 0.85 \\
\hline 6. & Thiourea & 0.97 \\
\hline
\end{tabular}

Table 4: $\mathrm{IC}_{50}$ values of extract/fractions

Kaleem et al., studied the urease inhibitory potential of Zizyphus oxyphylla edgew. extracts and isolated compounds. Methanolic extracts and some fractions were obtained from the stem and three compounds were isolated from the roots by using the column chromatography. These compounds were screened for their urease inhibition capacity using indophenol method. Studies revealed that extracts obtained from the zizyphus stem, ethyl acetate fraction showed the maximum inhibition of $86.7 \pm 0.03 \%$ when compared with the standard drug thiourea which showed urease inhibition of $98.1 \pm$ $0.02 \%$. Out of all isolated compounds from the roots of zizyphus oxyphylla, oxyphylline(D) (9) with $\mathrm{IC}_{50}=420.1 \pm$ $1.22 \mu \mathrm{M}$ showed the potent inhibitory activity compared with thiourea with $\mathrm{IC}_{50}=21 \pm 0.011 \mu \mathrm{M}$ against jack bean urease [76].

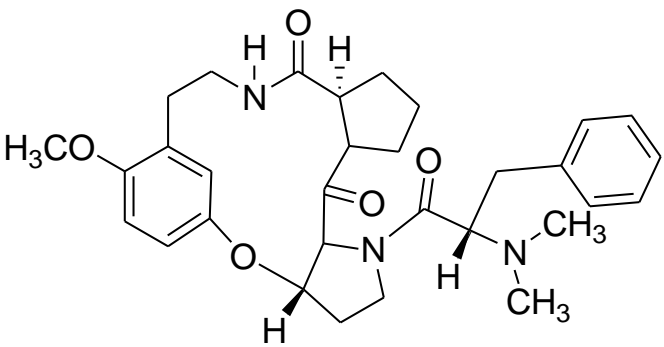

(9) 
Indo Global Journal of Pharmaceutical Sciences, 2019; 9(1): 42-53

\begin{tabular}{ccc}
\hline Sr. No. & Compounds & $\begin{array}{c}\text { Percentage } \\
\text { Inhibition }\end{array}$ \\
\hline 1. & Oxyphylline(D) & $58.2 \pm 0.02$ \\
2. & Nummularin(C) & $29.3 \pm 0.01$ \\
3. & Nummularin (R) & $35.7 \pm 0.02$ \\
4. & Thiourea & $98.1 \pm 0.2$ \\
\hline
\end{tabular}

Table 5 : Percentage inhibition of isolated compounds

Zahid et al., studied the antioxidant and urease inhibition activity of methanolic extracts of Hibiscus schizopetalus (Mask) Hook. Antioxidant assay was performed using the DPPH radical scavenging and nitric oxide scavenging activity. Urease inhibition potential was determined by using the indophenol method. Studies revealed that Hibiscus schizopetalus flower extracts showed the maximum inhibition capacity of $55.5 \%$ with $\mathrm{IC}_{50}=80.1 \pm 0.87 \mu \mathrm{g} / \mathrm{ml}$, when compared with the standard drug thiourea which showed inhibition of $98.2 \%$ with $\mathrm{IC}_{50}=88.2 \pm 0.1 \mu \mathrm{g} / \mathrm{ml}$, and ascorbic acid showed $81.02 \%$ inhibition against jack bean urease, where as Hibiscus schizopetalus leaves extracts showed the minimum inhibition activity i.e. 22.2\%. Extracts obtained from Hibiscus schizopetalus (Mask) Hook were found to be useful in gastric and urinary tract infections [77].

Khan et al., studied the aerial parts of Artemisia scoparia including crude methanolic extract, extracts of sterols, flavonoids and aqueous fraction. These parts are evaluated for urease inhibition activity using in-vitro study. Drugs synthesized from Artemisia scoparia are being used in the treatment of ulcers. Urease inhibition activity was measured by determining the production of ammonia using indophenols method. Studies revealed that flavanoidal extracts with $\mathrm{IC}_{50}$ $=2.10 \pm 0.01 \mathrm{mg} / \mathrm{ml}$ showed higher inhibition activity against jack bean urease when compared with standard drug thiourea which showed dose dependent activity with maximum inhibition of $91 \%$ at $100 \mu \mathrm{g} / \mathrm{ml}$ and flavanoidal extracts showed maximum inhibition of $86.17 \%$ at $10 \mathrm{mg} / \mathrm{ml}$, whereas sterol extracts showed least urease inhibition activity with $\mathrm{IC}_{50}=8.04 \pm 0.09 \mathrm{mg} / \mathrm{ml}[29]$.

Sokmen et al., carried out the synthesis of derivatives of arylidene barbiturates and these compounds were investigated for their antiurease, antibacterial, and antioxidant potential. Urease inhibition activity was determined by using indophenol method. Studies revealed that compounds 5-(2hydroxybenzylidene)-1,3-dimethylpyrimidine-

2,4,6(1H,3H,5H)-trione (10) and 5-(3-hydroxybenzylidene)1,3-dimethylpyrimidine-2,4,6(1H,3H,5H)-trione (11) with $\mathrm{IC}_{50}=0.036 \pm 0.002 \mu \mathrm{M}$ and $0.033 \pm 0.151 \mu \mathrm{M}$ respectively showed potent activity, when compared with the standard drug thiourea with $\mathrm{IC}_{50}=8.825 \pm 1.601 \mu \mathrm{M}$ and hydroxyurea with
$\mathrm{IC}_{50}=7.418 \pm 0.012 \mu \mathrm{M}$ against jack bean urease. Some synthesized derivatives of arylidene barbiturates showed good antibacterial and antioxidant activities. Because of their good antiurease, antibacterial, and antiurease activity, the synthesized arylidene barbiturates can be used in the industries and agriculture [78].<smiles>CN1C(=O)C(=Cc2ccccc2O)C(=O)N(C)C1=O</smiles>

(10)
(11)<smiles>CN1C(=O)C(=Cc2cccc(O)c2)C(=O)N(C)C1=O</smiles>

Bektas et al., synthesized morpholine derivatives containing an azole ring from the starting compound 6-morpholin-4ylpyridin-3-amine. Structures of morpholine derivatives were elucidated by using FTIR, EIMS, ${ }^{1} \mathrm{H}-\mathrm{NMR},{ }^{13} \mathrm{C}-\mathrm{NMR}$ spectroscopic techniques and elemental analysis. Synthesized derivatives were evaluated for their urease inhibition and antimicrobial potentials. Studies revealed that few derivatives were found to have good urease inhibition and antimicrobial potentials against Mycobacterium smegmatis, Candida albicans, and Saccharomyces cerevisiae. Compound $N^{\prime}-((5-$ (4-chlorophenyl)-3-phenyl-1,3-thiazole-2(3H)-ylidene)-2-((6morpholine-4-ylpyridin-3-yl)amino)acetohydrazide showed potent urease inhibition activity with $\mathrm{IC}_{50}=2.37 \pm$ $0.19 \mu \mathrm{M}[79]$.

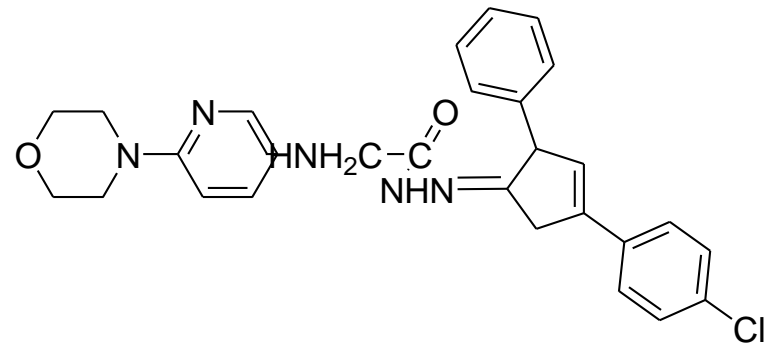

(12)

Amin et al., carried out the anti-helicobacter pylori and urease inhibition potentials of some traditional medicinal plants like Acacia nilotica (L) Delile, Calotropis procera (W.T.) Aiton, Adhatoda vasica Nees, Fagoniaar abica L. and Casuarinas equisetifolia L. etc. Methanol, acetone and water extracts of the plants were evaluated by phenol red method for determination of their helicobacter pylori and urease inhibition activities. Agar dilution method was used to obtaine the minimum inhibitory concentration (MIC) of the plants extracts and compared with standard antibiotics like amoxicillin, clarithromycin, tetracycline and metronidazole. Methanol and acetone extracts of some medicinal plants showed stronger anti-helicobacter pylori activity like Acacia 


\section{Indo Global Journal of Pharmaceutical Sciences, 2019; 9(1): 42-53}

nilotica calotropis plant than metronidazole and approximately similar activity as tetracycline [32].

Lateef et al., evaluated the roots of Glycyrrhiza glabra for antioxidant and urease inhibition activities. Methanolic extract was used for urease inhibition activity. Ethyl acetate, chloroform and butanol were used for fractionation of methanolic extracts. Antioxidant acivity was measured by using the DPPH radical scavenging activity. Urease inhibition activity was measured by using indophenol method. Out of all fractions, ethylacetate fraction showed the maximum inhibition i.e. $72 \%$ when compared with the standard drug thiourea which showed $94 \%$ inhibition against jack bean urease. Studies revealed that roots of Glycyrrhiza glabra is a potential source of antioxidant and urease inhibitors. Thus, our study validated the traditional use of Glycyrrhiza glabra in the treatment of ulcer [80].

Arfan et al., carried out the urease inhibition activity of the compounds isolated from Hypericum oblongifolium WALL. Various fractions were obtained after extraction with hexane $\left(\mathrm{F}_{1}\right)$, ethyl acetate $\left(\mathrm{F}_{2}\right)$, and methanol. Methanolic fraction was further extracted with n-butanol after suspending in water and obtained fractions of butanol $\left(\mathrm{F}_{3}\right)$ and water $\left(\mathrm{F}_{4}\right)$. Three compounds were isolated from fractionation of Hypericum oblongifolium. Structures of these derivatives were screened by NMR and mass spectroscopic techniques. Urease inhibition activity was measured by using the indophenols method against jack bean urease. Studies revealed that ethyl acetate and water fractions showed potent inhibitory activity with $\mathrm{IC}_{50}=140.37 \pm 1.93$ and $167.43 \pm 3.03 \mu \mathrm{M}$, when compared with standard inhibitor thiourea with $\mathrm{IC}_{50}=21.01 \pm$ $0.51 \mu \mathrm{M}$. Out of all isolated compounds, tetracosyl 3-(3,4dihydroxyphenyl) acrylate (13) was observed to show highest urease inhibitory activity with $\mathrm{IC}_{50}=20.96 \pm 0.93 \mu \mathrm{M}$ [81].

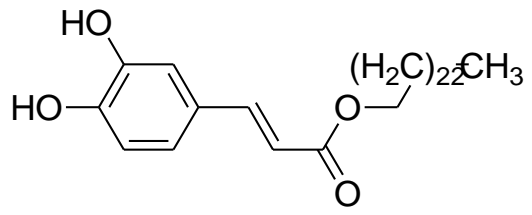

(13)

Taha et al., synthesized the 3,4,5-trihydroxybenzohydrazones from 3,4,5-trihydroxybenzohydrazide and evaluated them for urease inhibition activity. 3,4,5-trihydroxybenzohdrazide was synthesized from methyl-3,4,5-trihydroxybenzoate after refluxing with hydrazine hydrate. All synthesized derivatives were characterized by NMR and mass spectroscopic techniques. Urease inhibition activity was determined by using the indophenol mehod. Kinetic studies showed that $(E)$ $N$ '-(furan-2-ylmethylene)-3,4,5-trihydroxybenzohydrazide
(14) and (E)-3,4,5-trihydroxy- $N$-(3-hydroxybenzylidene) benzohydrazide (15) derivatives had potent inhibitory activities with $\mathrm{IC}_{50}=28.09 \pm 1.2 \mu \mathrm{M}$ and $27.20 \pm 1.2 \mu \mathrm{M}$ against jack bean urease when compared with positive control thiourea with $\mathrm{IC}_{50}=21.20 \pm 1.30 \mu \mathrm{M}$ [63].<smiles>CC/C=N/NC(=O)c1cc(O)c(O)c(O)c1</smiles>

(14)<smiles>O=C(N/N=C/Cc1ccccc1)c1cc(O)c(O)c(O)c1</smiles>

(15)
Muhammad et al., studied the synthesis of eighteen 1,3,4oxadiazole derivatives and these derivatives were screened for their urease inhibition, antioxidant, and anti-bacterial activities. Urease inhibition activity was measured by using indophenol method. Molecular docking studies were also performed to observed the mode of interaction of synthesized derivatives. Studies revealed that 5-(4-chlorobenzyl)-1,3,4oxadiazole-2( $3 H)$-thione $(16)$ with $\mathrm{IC}_{50}=1.15 \pm 0.2 \mu \mathrm{M}$ was found to have potent activity against jack bean urease when compared with positive control thiourea with $\mathrm{IC}_{50}=22.3 \pm 1.2$ $\mu \mathrm{M}$. Some derivatives also showed good antioxidant and antibacterial activities [46].<smiles>S=c1[nH]nc(Cc2ccc(Cl)cc2)o1</smiles>

(16)

Taha et al., carried out the synthesis of a series of 2methoxybenzoylhydrazone derivatives and these compounds were evaluated for urease and $\alpha$-glucosidase inhibition activities. Urease inhibition activity was measured by using indophenol method. Studies revealed that compounds $N^{\prime}$ (3,4,5-trihydroxybenzylidiene)-2-methoxybenzohydrazide and $N^{\prime}$-(3,5-dihydroxybenzylidene)-2methoxybenzohydrazide (18) had potent activity with $\mathrm{IC}_{50}=21.6 \pm 0.6 \mu \mathrm{M}$ and $19.6 \pm 1.0 \mu \mathrm{M}$ when compared with positive control thiourea with $\mathrm{IC}_{50}=21.8 \pm 1.6 \mu \mathrm{M}$. Some derivatives were found to have good $\alpha$-glucosidase inhibition activity when compared with acarbose [62].<smiles>C/C=C(\CC)C(=O)N/N=C/c1cc(O)cc(O)c1</smiles>

(18) 
Indo Global Journal of Pharmaceutical Sciences, 2019; 9(1): 42-53

Macegoniuk et al., studied the synthesis of 1,2benzisoselenazol-3(2H)-one derivatives as inhibitors of bacterial ureases. These compounds were evaluated for inhibition activity against Sporosarcina pasteurii and Helicobactor pylori ureases and measured the production of ammonia using phenol-hypochlorite method. Kinetic parameters were measured by using the Michaelis-Menten equation, which gave the Ki value of compound 2-phenyl-1,2benzisoselenazol-3(2H)-one (ebselen) i.e. $2.11 \pm 0.18 \mathrm{nM}$ against Sporosarcina pasteurii and $226 \pm 16 \mathrm{nM}$ against Helicobacter pylori urease in comparison with standard acetohydroxamic acid ( $K i$ is $3300 \pm 400 \mathrm{nM}$ ). Studies indicated ebselen (19) as one of the low molecular weight inhibitor which showed potent activity against bacterial ureases. Studies of urease inhibition in whole Helicobactor pylori $\mathrm{J} 99$ strain also showed the potent activity of the studied 1,2benzisoselenazol-3(2H)-one derivatives as inhibitors of bacterial ureases [61].<smiles>O=c1c2ccccc2[se]n1-c1ccccc1</smiles>

(19)

Chen et al., studied the derivatives of gossypol inhibitors of jack bean urease and these compounds were evaluated experimently and theoretically for inhibition activity. The binding free energies, action sites, inhibition constants and hydrogen bonds were calculated using Autodock. The binding free energies of gossypol $(-4.39 \mathrm{Kcal} / \mathrm{mol})$, gossypolone ($4.91 \mathrm{Kcal} / \mathrm{mol})$, and apogossypol $(-7.07 \mathrm{Kcal} / \mathrm{mol})$ were determined. Urease inhibition activity was determined by indophenols red method. From experimental data $\mathrm{IC}_{50}$ values were calculated i.e. $110 \mu \mathrm{M}$ for gossypol, $51.7 \mu \mathrm{M}$ for gossypolone and $9.8 \mu \mathrm{M}$ for apogossypol, respectively. From the docking and experimental data it was indicated that the phenolic hydroxyl groups of gossypol i.e. 1,1'-OH, gossypolone i.e. 6,6'-OH, and apogossypol i.e. 7,7'-OH played an important role in the jack bean urease inhibition. Out of all gossypol derivatives apogossypol (20) showed the most potent inhibitory activity against jack bean urease [82].<smiles>Cc1cc2c(C(C)C)c(O)c(O)cc2c(O)c1-c1c(C)cc2c(C(C)C)c(O)c(O)cc2c1O</smiles>

(20)

Berlicki et al., synthesized the $N$-substituted derivatives of aminomethanephosphonic and aminomethane- $p$ methylphosphinic acids. These derivatives were evaluated for urease inhibitior activity using indophenols method against Canavalia ensiformis and Bacillus pasteurii urease. Studies revealed compounds $\mathrm{N}, \mathrm{N}$-dimethylaminomethanephosphonic acid (21) and $N, N$-dimethylaminomethane- $p$ methylphosphinic acid (22) with $\mathrm{IC}_{50}=82 \pm 26$ and $14.4 \pm$ $4.8 \mu \mathrm{m}$ against Canavalia ensiformis urease, $\mathrm{IC}_{50}=49 \pm 1.7$ and $3.8 \pm 0.4 \mu \mathrm{m}$ against Bacillus pasteurii urease when compared with standard inhibitor acetohydroxamic acid with $\mathrm{IC}_{50}=64.6$ $\pm 3 \mu \mathrm{m}$. Whole cell activity showed that derivatives of aminomethane-p-methylphosphinic acid had higher inhibition activity than $N, N$-dimethyl derivatives [83].<smiles>CN(C)CP(=O)(O)O</smiles>

(21)<smiles>CN(C)CP(C)(=O)O</smiles>

(22)
Afza et al., studied the schiff base ligand and its complex whose structure was characterized by elemental analysis, molar conductance, ${ }^{1} \mathrm{H}-\mathrm{NMR}$, FTIR and FAB-Mass spectroscopic techniques and these were evaluated for urease inhibition activity using indophenol method. Studies revealed that $2-\{[(2-\{[(E)$-(2-hydroxyphenyl) methylidene $]$ amino $\}$ ethyl) imino] methyl $\}$ phenol-copper (II) complex (23) with $\mathrm{IC}_{50}=19.0 \mu \mathrm{M}$ was found to be potent inhibitor when compared with positive control thiourea with $\mathrm{IC}_{50}=21.6 \mu \mathrm{M}$ [84].

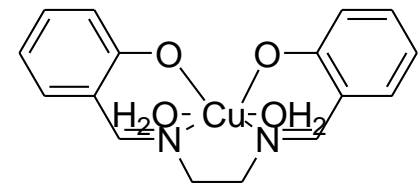

(23)

Bekiracan et al., studied the synthesis of new fluorinecontaining 1,2,4-triazole-5-one derivatives and structure of these compounds were characterized by $\mathrm{IR},{ }^{1} \mathrm{H}$ and ${ }^{13} \mathrm{C}$ NMR techniques and were evaluated for antiurease, antixanthine oxidase and antioxidant activities. Urease inhibition activity was determined by using indophenol method. Studies revealed that compounds 4-amino-5-(2-fluorobenzyl)-2-(\{4[(4-trifluoromethoxyphenylamino)methyl]-5-thioxo-1,3,4oxadiazol-2-yl \}methyl)-2,4-dihydro-3H-1,2,4-triazol-3-one and 4-Amino-5-(4-fluorobenzyl)-2-(\{4-[(4trifluoromethoxyphenylamino)methyl]-5-thioxo-1,3,4oxadiazol-2-yl \}methyl)-2,4-dihydro-3H-1,2,4-triazol-3-one with $\mathrm{IC}_{50}=29.34 \pm 0.36$ and $28.89 \pm 0.11 \mu \mathrm{m}$ were found good inhibitors of jack bean urease when compared with standard drug thiourea with $\mathrm{IC}_{50}=63.72 \pm 0.23 \mu \mathrm{m}$. Some derivatives also showed good antixanthine oxidase and antioxidant activity [85]. 


\section{Indo Global Journal of Pharmaceutical Sciences, 2019; 9(1): 42-53}

Shi et al., synthesized two Schiff base zinc (II) complexes and structure of these complexes were clarified by IR and NMR techniques. These complexes were screened for urease inhibition potential using indophenols method. Studies revealed that $\mathrm{ZnBr}_{2} \mathrm{~L}^{2}$ complex showed $35.63 \pm 1.45 \%$ inhibition, when compared with positive control acetohydroxamic acid which showed $88.23 \pm 2.08 \%$ inhibition against jack bean urease [86].

Shahzad et al., studied microwave-assisted solvent free efficient synthesis of 5-substituted-1,2,4-oxadiazole-2(3H)thiones derivatives which were screened for urease inhibition activity using indophenol method. Out of all derivatives 5(2'-bromophenyl-1,3,4-oxadiazole-2 $(3 H)$-thione (24) and 5(4'-bromophenyl-1,3,4-oxadiazole-2(3H)-thione (25) with $\mathrm{IC}_{50}=12.60 \pm 0.92$ and $13.03 \pm 1.80 \mu \mathrm{M}$ were found most active inhibitors of jack bean urease compared with standard drug thiourea with $\mathrm{IC}_{50}=21 \mu \mathrm{M}$ [87].

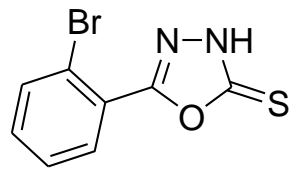

(24)

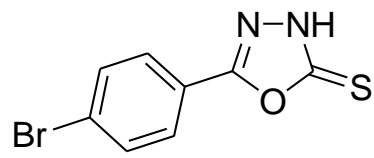

(25)
Saeed et al., carried out the synthesis of some iminothiazolinesulfonamide hybrids and these derivatives were screened for urease inhibition potential using indophenols method. Studies revealed that (Z)- $N$-(3-(4-aminosulfonylphenyl)-4methylthiazol-2(3H)-ylidene)-3-flourobenzamide (26) and (Z)- $N$-(3-(4-aminosulfonylphenyl)-4-methylthiazol-2(3H)ylidene)-2-chloro-4-nitrobenzamide (27) with $\mathrm{IC}_{50}=0.064 \pm$ 0.01 and $0.058 \pm 0.011 \mu \mathrm{M}$ were found potent inhibitors of jack bean urease when compared with positive control thiourea with $\mathrm{IC}_{50}=20.9 \pm 0.92 \mu \mathrm{M}$. The kinetic mechanism studies showed that (Z)- $N$-(3-(4-aminosulfonylphenyl)-4methylthiazol-2(3H)-ylidene)-3-flourobenzamide is a mixed type inhibitor but (Z)- $N$-(3-(4-aminosulfonylphenyl)-4methylthiazol-2(3H)-ylidene)-2-chloro-4-nitrobenzamide is a competitive inhibitor [88].<smiles>Cc1cs/c(=N\C(=O)c2cccc(F)c2)n1-c1ccc(S(=O)(=O)O)cc1</smiles><smiles>Cc1cs/c(=N\C(=O)c2ccc([N+](=O)[O-])cc2Cl)n1-c1ccc(S(=O)(=O)O)cc1</smiles>

Barakat et al., synthesized several barbituric acid derivatives and structure of these compounds were characterized using IR,
${ }^{1} \mathrm{H}$ and ${ }^{13} \mathrm{C}$ NMR and mass spectroscopic techniques. These derivatives were evaluated for urease inhibitory activity using indophenol method. Out of all derivatives 4-((6-hydroxy-1,3dimethyl-2,4-dioxo-1,2,3,4-tetrahydropyrimidin-5-yl), (6hydroxy-2,4-dioxo-1,2,3,4-tetrahydropyrimidin-5yl)methyl)benzaldehyde diethylaminium salt and 5,5'-( $p$ tolylmethylene)bis(6-hydroxypyrimidine-2,4(1H,3H)-dione) diethylaminium salt with $\mathrm{IC}_{50}=17.2 \pm 0.44$ and $17.6 \pm 0.23 \mu \mathrm{M}$ showed excellent jack bean urease inhibiting activity when compared with positive control thiourea with $\mathrm{IC}_{50}=21.2 \pm$ $1.3 \mu \mathrm{M}$. Molecular dynamic stimulation was also carried out to measure the binding interaction of synthesized derivatives with urease which showed that enol form was more established due to their coordination [52].

You et al., synthesized 2,5-disubstituted-1,4-benzoquinone derivatives and the structure of these derivatives were confirmed by IR, ${ }^{1} \mathrm{H}$ and ${ }^{13} \mathrm{C}$ NMR and single crystal X-ray determination techniques. These derivatives were evaluated for urease inhibition activity using indophenol method. Studies revealed that 2,5-bis (2-morpholin-4-ylethylamino)$[1,4]$ benzoquinone with $\mathrm{IC}_{50}=27.30 \pm 2.17 \mu \mathrm{M}$ was found active against Helicobacter pylori urease. Molecular docking studies were also carried out to analyze the binding interaction of between enzyme active centre with synthesized derivatives in which compound 2,5-bis(2-morpholin-4-ylethylamino)$[1,4]$ benzoquinone was found as potent inhibitor [53] .

Thadhani et al., synthesized several mononuclear phenolic lichen compounds and these were evaluated for urease inhibition activity using indophenol method. Out of all compounds orsellinic acid (28) and orcinol (29) with $\mathrm{IC}_{50}=4.50 \pm 0.14$ and $11.2 \pm 0.2 \mu \mathrm{M}$ were found excellent urease inhibitor when compared with standard inhibitor thiourea with $\mathrm{IC}_{50}=21.01 \pm 0.5 \mu \mathrm{M}$. This study proved that polyphenolic lichen compounds were potent urease inhibitors [89].<smiles>Cc1cc(O)cc(O)c1C(=O)O</smiles>

(28)<smiles>Cc1cc(O)cc(O)c1</smiles>

(29)

\section{REFERENCES}

1) Mobley, H.L.T., Hausinger, R.P. Microbial ureases: significance, regulation, and molecular characterization. Microbial. Rev., 1989; 53(1): 85-108.

2) Holm, L., Sander, C. An evolutionary treasure: unification of a broad set of amidohydrolases related to urease. Proteins, 1997; 28(1): 72-82. 


\section{Indo Global Journal of Pharmaceutical Sciences, 2019; 9(1): 42-53}

3) Sumner, J.B. The isolation and crystallization of the enzyme urease. J. Biol. Chem., 1926; 69: 435-441.

4) Yu, J.J., Smithson, S.L., Thomas, P.W., Kirkland, T.N., Cole, G.T. Isolation and characterization of the urease gene (URE) from the pathogenic fungus Coccidioides immitis. Gene, 1997; 198(1-2): 387-391.

5) Sirko, A., Brodzik, R. Plant ureases, roles and regulation. Acta. Biochimica. Polonica, 2000; 47: 1189-1195.

6) Zonia, L.E., Stebbins, N.E., Polacco, J.C. Essential role of urease in germination of nitrogen-limited Arabidopsis thaliana seeds. Plant. Physiol., 1995; 107(4): 1097-1103.

7) Callahan, B.P., Yuan, Y., Wolfenden, R. The burden borne by urease. J. Am. Chem. Soc., 2005; 127: 10828-10829.

8) Carter, E.L., Flugga, N., Boer, J.L. Interplay of metal ions and urease. Metallomics., 2009; 1: 207-221.

9) Dunn, B.E., Phadnis, S.H. Structure, Function and Localization of Helicobacter pylori Urease. Yale. J. Biol. Med., 1998; 71(2): 6373.

10) Follmer, C. Ureases as a target for the treatment of gastric and urinary infections. J. Clin. Pathol., 2010; 63(5): 424-430.

11) Collins, C.M., Orazio, S.E.F.D. Bacterial Ureases: Structure, Regulation of Expression and Role in Pathogenesis. Mol. Microbiol., 1993; 9: 907-913.

12) Nguyen, D.M., Seo, D.J. Lee, H.B., Kim, I.S., Kim, K.Y., Park, R.D., Jung, W.J. Antifungal activity of gallic acid purified from Terminalia nigrovenulosa bark against Fusarium solani. Microbiol. Pathog., 2013; 56: 8-15.

13) Arabski, M., Konieczna, I., Sołowiej, D., Rogoń, A., Kolesińska, B., Kamiński, Z., Kaca, W. Are anti-Helicobacter pylori urease antibodies involved in atherosclerotic diseases? Clin. Biochem., 2010; 43(1): 115-123.

14) Berdoz, J., Corthesy, B. Human polymeric $\operatorname{IgA}$ is superior to $\operatorname{IgG}$ and single-chain $\mathrm{Fv}$ of the same monoclonal specificity to inhibit urease activity associated with Helicobacter pylori. Mol. Immunol., 2004; 41: 1013-1022.

15) Wisniewska, M., Nilsson, H.O., Romaniszyn, B.L., Rechcinski, T., Bielanski, W., Malecka, P.I., Plonka, M., Konturek, S., Wadstrom, T., Rudnicka, W., Chmiela, M. Detection of specific Helicobacter pylori DNA and antigens in stool samples in dyspeptic patients and healthy subjects. Microbiol. Immunol., 2004; 46: 657-665.

16) Atherton, J.C. The pathogenesis of Helicobacter pylori-induced gastro-duodenal diseases. Annu. Rev. Pathol., 2006; 1: 63-96.

17) Kusters, J.G., Vliet, A.H.M.V., Kuipers, E.J. Pathogenesis of Helicobacter pylori Infection. Clin. Microbiol. Rev., 2006; 19: 449-490.

18) Jabbar, A., Zaman, M.A., Iqbal, Z., Yaseen, M., Shamim, A. Anthelmintic activity of Chenopodium album (L.) and Caesalpinia crista (L.) against trichostrongylid nematodes of sheep. J. Ethnopharmacol., 2007; 114(1): 86-91.

19) Nardini, M., Ghiselli, A. Determination of free and bound phenolic acids in beer. Food. Chem., 2004; 84: 137-143.

20) Koshihara, Y., Neichi, T., Murota, S.I. Caffeic acid is a selective inhibitor for leukotriene biosynthesis. Biochimica. Et. Biophisica. Acta., 1984; 792: 92-97.

21) Heleno, S.A., Martins, A., Queiroz, M.J.R., Ferreira, I.C. Bioactivity of phenolic acids: Metabolites versus parent compounds: A review. Food chem., 2015; 173: 501-513.

22) Singh, M., Jha, A., Kumar, A., Hettiarachchy, N., Rai, A.K., Sharma, D. Influence of the solvents on the extraction of major phenolic compounds (punicalagin, ellagic acid and gallic acid) and their antioxidant activities in pomegranate aril. J. Food. Sci. Technol., 2014; 51(9): 2070-2077.

23) Roberto, D.G., Remigio, L.S., Elias, O.S. Comparative antibacterial effect of gallic acid and catechin against Helicobacter pylori. LWT - Food. Sci. Technol., 2013; 54: 331-335.

24) Jang, M., Jeong, S.W., Cho, S.K., Ahn, K.S., Kim, B.K., Kim, J.C. Anti-inflammatory effects of 4 medicinal plant extracts in lipopolysaccharide-induced RAW 264.7 cells. Food. Sci. Biotechnol., 2013; 22(1): 213-220.

25) Parihar, S., Gupta, A., Chaturvedi, A.K., Agarwal, J., Lugman, S., Chanqkija, B., Manohar, M., Chanda, D., Chanotiya, C.S., Shanker, K., Dwivedi, A., Konwar, R., Neqi, A.S. Gallic acid based steroidal phenstatin analogues for selective targeting of breast cancer cells through inhibiting tubulin polymerization. Steroids, 77(8-9): 878-886.

26) Gandhi, G.R., Jothi, G., Antony, P.J., Balakrishna, K., Paulraj, M.G., Lgnachimuthu, S., Stalin, A., Dhabi, N.A.A. Gallic acid attenuates high-fat diet fed-streptozotocin-induced insulin resistance via partial agonism of PPAR $\gamma$ in experimental type 2 diabetic rats and enhances glucose uptake through translocation and activation of GLUT4 in PI3K/p-Akt signaling pathway. Eur. J. Pharmacol., 2014; 745: 201-216.

27) Dunn, B.E., Cohen, H., Blaser, M.J. Inhibition of Helicobacter pylori. Clin. Microbiol. Rev., 1997; 10: 720-741.

28) Amtul, Z., Rasheed, M., Choudhary, M.I. Rosanna, S., Khan, K.M., Atta, R. Kinetics of novel competitive inhibitors of urease enzymes by a focused library of oxadiazoles/thiadiazoles and triazoles. Biochem. Biophys. Res. Commun., 2004; 319: 10531063.

29) Khan, M.A., Khan, H., Tariq, S.A., Pervez, S. Urease inhibitory activity of aerial parts of Artemisia scoparia: exploration in an in vitro study. Hindawi. Publishing. Corporation, 2014; 1-5.

30) Nabati, F., Mojab, F., Habibi-Rezaei, M., Bagherzadeh, K., Amanlou, M., Yousefi, B. Large scale screening of commonly used Iranian traditional medicinal plants against urease activity. DARU. J. Pharm. Sci., 2012; 20(1): 72.

31) Biglar, M., Soltani, K., Nabati, F., Bazl, R., Mojab, F., Amanlou, M. A preliminary investigation of the jack-bean urease inhibition by randomly selected traditionally used herbal medicine. Iran. J. Pharm. Res., 2012; 11(3): 831.

32) Amin, M., Anwar, F., Naz, F., Mehmood, T., Saari, N. AntiHelicobacter pylori and urease inhibition activities of some traditional medicinal plants. Molecules, 2013; 18: 2135-2149.

33) Xiao, Z.P., Peng, Z.Y., Dong, J.J, Deng, R.C., Wang, X.D., Ouyang, H., Yang, P., He, J., Wang, Y.F., Zhu, M., Peng, X.C., Peng, W.X., Zhu, H.L. Synthesis, molecular docking and kinetic properties of $\beta$-hydroxy- $\beta$-phenylpropionyl-hydroxamic acids as Helicobacter pylori urease inhibitors. Eur. J. Med. Chem., 2013; 68: 212-221.

34) Olech, Z., Zaborska, W., Kot, M. Jack bean urease inhibition by crude juices of Allium and Brassica plants, Determination of thiosulfinates. Food. Chem., 2014; 145: 154-60.

35) Ahmad, I., Chaudhary, B.A., Janbaz, K.H., Uzair, M., Ashraf, M. Vernonione, A new urease inhibitory carvotacetone derivative from Vernonia cinerascens. J. Chem. Soc. Pak., 2011; 33: 114 117.

36) Akhtar, N., Saleem, M., Riaz, N., Shaiq, Ali M., Yaqoob, A., Nasim, F., Jabbar, A. Longipetalosides A-C, new steroidal saponins from Tribulus longipetalus. Phytochem. Lett., 2013; 6: 291-298.

37) Ramsay, K.S., Wafo, P., Ali, Z., Khan, A., Oluyemisi, O., Marasini, B.P., Khan, I.A., Bonaventure, N.T. Choudhary, M.I., Chemical constituents of Stereospermum acuminatissimum and their urease and alpha-chymotrypsin inhibitors. Fitoterapia, 2012; 83: 204-208

38) Ngan, L.T., Moon, J.K., Shibamoto, T., Ahn, Y.J. Growthinhibiting, bactericidal, and urease inhibitory effects of Paeonia lactiflora root constituents and related compounds on antibioticsusceptible and resistant strains of Helicobacter pylori. Agric. J. Food. Chem., 2012; 60: 9062-9073.

39) Arfan, M., Amin, H., Khan, I., Shah, M.R., Shah, H., Khan, A.Z., Halimi, S.M.A., Khan, N., Kaleem, W.A., Qayum, M., Shahidullah, A., Khan, M.A. Molecular simulations of bergenin as a new urease inhibitor, Med. Chem. Res., 2012; 21: 2454 2457.

40) Mansoor, F., Anis, I., Khan, A., Marasini, B.P., Choudhary, M.I., Shah, M.R. Urease inhibitory constituents from Daphne retusa. J. Asian. Nat. Prod. Res., 2014; 16: 210-215.

41) Tan, L., Su, J., Wu, D., Yu, X., Su, Z., He, J., Wu, X., Kong, S., Lai, X., Lin, J., Su, Z. Kinetics and mechanism study of competitive inhibition of jack bean urease by baicalin. Scientific World Journal, 2013; 879501.

42) Wu, D.W., Yu, X.D., Xie, J.H., Su, Z.Q., Su, J.Y., Tan, L.R., Huang, X.Q., Chen, J.N., Su, Z.R. Inactivation of jack bean urease by scutellarin: Elucidation of inhibitory efficacy, kinetics and mechanism. Fitoterapia, 2013; 91: 60-67. 


\section{Indo Global Journal of Pharmaceutical Sciences, 2019; 9(1): 42-53}

43) Ali, M., Latif, A., Zaman, K., Arfan, M., Maitland, D., Ahmad, H., Ahmad, M. Anti-ulcer xanthones from the roots of Hypericum oblongifolium Wall. Fitoterapia, 2014; 95: 258-265.

44) Shrestha, R.L.S., Adhikari, A., Marasini, B., Jha, R.N., Choudhary M.I. Novel inhibitors of urease from Corydalis govaniana Wall. Phytochem. Lett., 2013; 228-231.

45) Uddin, N., Siddiqui, B.S., Begum, S., Ali, M.I., Marasini, B.P., Khan, A., Choudhary, M.I. Bioassay-guided isolation of urease and $\alpha$-chymotrypsin inhibitory constituents from the stems of Lawsonia alba Lam. (Henna). Fitoterapia, 2013; 84: 202-207.

46) Muhammad, N., Saeed, M., Khan, A., Adhikari, A., Wadood, A., Khan, K.M. A new urease inhibitor from Viola betonicifolia. Molecules, 2014; 19: 16770-16778.

47) Tariq, S.A., Ahmad, S.A., Obaidullah, Khan, A., Choudhary, M.I., Ahmad, W., Ahmad, M. Urease inhibitors from Indigofera gerardiana Wall. J. Enzyme. Inhib. Med. Chem., 2011; 26: 480484.

48) Paulo, L., Oleastro, M., Gallardo, E.J., Queiroz, F., Domingues, F. Anti-Helicobacter pylori and urease inhibitory activities of resveratrol and red wine. Food. Res. Int., 2011; 44: 964-969.

49) Perveen, S., Shafae, M.A., Taweel, A., Fawzy, G.A., Malik, A., Afza, N., Latif, M.L.I., Iqbal, L.I. Antioxidant and urease inhibitory C-glycosylflavonoids from Celtis Africana. J. Asian. Nat. Prod. Res., 2011; 13: 799-804.

50) Taha, M., Ismail, N.H., Baharudin, M.S., Lalani, S., Mehboob, S., Khan, K.M., yousuf, S., Siddiqui, S., Rahim, F., Choudhary, M.I. Synthesis crystal structure of 2-methoxybenzoylhydrazones and evaluation of their a-glucosidase and urease inhibition potential. Med. Chem. Res., 2015; 24: 1310-1324.

51) Adsul, L.K., Bandgar, B.P., Chavan, H.V., Jalde, S.S., Dhakane, V.D., Shirfule, A.L. Synthesis and biological evaluation of novel series of aminopyrimidine derivatives as urease inhibitors and antimicrobial agents. J. Enzym. Inhib. Med. Ch., 2013; 28(6): 1316-1323.

52) Barakat, A., Al-Majid, A.M., Lotfy, G., Arshad, F., Yousuf, S., Choudhary, M.I., Ashraf, S., Ul-Haq, Z. Synthesis and dynamics studies of barbituric acid derivatives as urease inhibitors. Chemistry. Central. Journal., 2015; 9(63): 1-15.

53) You, Z., Xian, D., Zhang, M., Xiao, S., Xiao, F. Synthesis, biological evaluation, and molecular docking studies of 2,5substituted-1,4-benzoquinone as novel urease inhibitors. Bioorg. Med. Chem., 2012; 20: 4889-4894.

54) Francesco, V.D., Ierardi, E., Hassan, C. Helicobacter pylori therapy: present and future. World. J. Gastrointest. Pharmacol. Ther., 2012; 3(4): 68-73.

55) Pervez, H., Ahmad, M., Zaib, S., Yaqub, M., Iqbal, J. Synthesis, cytotoxic and urease inhibitory activities of some novel isatin derived bis-Schiff bases and their copper (II) complexes. Royal Society of Chemistry, 2016; 6(2): 78-82.

56) Hanif, M., Shoaib, K., Saleem, M., Rama, N.H., Zaib, S. Synthesis, urease inhibition, antioxidant, antibacterial, and molecular docking studies of 1,3,4-Oxadiazole derivatives. ISRN. Pharmacol., 2012; 5: 93.

57) Vassiliou, S.A., Grabowiecka, P., Kosikowska, L., Berlicki. Three component kabachnik-fields condensation leading to substituted aminomethane-phydroxymethyl-phosphonic acids as a tool for screening of bacterial urease inhibitors. Arkivoc, 2012; 33-43.

58) Hameed, A., Anwar, A., Khan, K.M., Malik, R., Shahab, F., Siddiq, S., Basha, F.Z. Choudhary, M.I. Urease inhibition and anticancer activity of novel polyfunctional 5,6-dihydropyridine derivatives and their structure-activity relationship. Eur. J. Chem., 2013; 4(1): 49-52.

59) Xiao, Z.P., Shi, W.K., Wang, P.F., Wei, W., Zeng, X.T., Zhang, J.R., Zhu, N., Peng, M., Peng, B., Lin, X.Y., Ouyang, H., Peng, X.C., Wang, G.C., Zhu, H.L. Synthesis and evaluation of Nanalogs of 1,2-diarylethane as Helicobacter pylori urease inhibitors. Birroq. Med. Chem., 2015; 23(15): 4508-4513.

60) Shi, W.K., Deng, R.C., Wang, P.F., Yue, Q.Q., Liu, Q., Ding, K.L., Yang, M.H., Zhang, H.Y., Gong, S.H., Deng, M., Liu, W.R., Feng, Q.J., Xiao, Z.P., Zhu, H.L. 3Arylpropionylhydroxamic acid derivatives as Helicobacter pylori urease inhibitors: Synthesis, molecular docking and biological evaluation. Bioorg. Med. Chem., 2016; 24(19): 4519-4527.
61) Macegoniuk, K., Grela, E., Palus, J., Rudzin, E., Biernat, M., Berlicki, L. 1,2-Benzisoselenazol-3(2H)-one derivatives as a new class of bacterial urease inhibitors. J. Med. chem., 2016; 27: 350370 .

62) Taha, M., Ismail, H., Baharudin, M.S., Lalani, S., Mehboob, S., Khan, K.M., Siddiqui, S., Choudhary, M.I. Synthesis crystal structure of 2-methoxybenzoylhydrazones and evaluation of their a-glucosidase and urease inhibition potential. Med. Chem. Res., 2014; 24: 1310-1324.

63) Taha, M., Shah, S., Khan, A., Arshad, F., Ismail, N., Afifi, M., Imran, S., Choudhary, M.I. Synthesis of 3,4,5trihydroxybenzohydrazone and evaluation of their urease inhibition potential. Arabian Journal of Chemistry, 2015; 5: 735739.

64) Gull, Y., Rasool, N., Noreen, M., Nasim, F.H., Yaqoob, A., Kousar, A., Rashid, U., Bukhari, I.H., Zubair, M., Islam, M.S. Efficient Synthesis of 2-Amino-6-Arylbenzothiazoles via $\operatorname{Pd}(0)$ Suzuki Cross Coupling Reactions: Potent Urease Enzyme Inhibition and Nitric Oxide Scavenging Activities of the Products. Molecules., 2013; 18(8): 8845-8857.

65) Vo, T.S., Ngo, D.H., Kim, S.K. Gallic acid-grafted chitooligosaccharides suppress antigen-induced allergic reactions in RBL-2H3 mast cells. Eur. J. Pharm. Sci., 2012; 47: 527-533.

66) Sun, X., Wang, Z., Kadouh, H., Zhou, K. The antimicrobial, mechanical, physical and structural properties of chitosan-gallic acid films. LWT - Food. Sci. Technol., 2013; 57(1): 83-89.

67) Khatkar, A., Nanda, A., Kumar, P., Balasubramanian, N. Synthesis, antimicrobial evaluation and QSAR studies of gallic acid derivatives. Arabian Journal of Chemistry, 2013; 10(2): 28702880.

68) Saify, Z.S., Sultana, N., Khan, A., Haider, S. (1H-Pyrrolo [2,3$b$ ]pyridine)7-Azaindole derivatives and their Antiurease, Phosphodiesterase and $\beta$-glucuronidase Activity. Int. J. Biochem. Res. Rev., 2015; 8(1): 1-12.

69) Ziarani, G.M., Faramarzi, S., Asadi, S., Badiei, A., Bazl, R., Amanlou, M. Three-component synthesis of pyrano[2,3-d]pyrimidine dione derivatives facilitated by sulfonic acid nanoporous silica (SBA-Pr-SO3H) and their docking and urease inhibitory activity. DARU. J. Pharm. Sci., 2013; 21(3): 1-13.

70) Khan, K.M., Rahim, F., Khan, A., Ali, S., Taha, M., Saad, S.M., Khan, M., Najeebullah, Shaikh, A., Perveen, S., Choudhary M.I. Synthesis of benzophenone hydrazone analogs and their DPPH radical scavenging and urease inhibitory activities. J. Chem. Soc. Pak., 2015; 37(3): 479-483.

71) Ahmed, D., Younas, S., Mughal, Q.M.A. Study of alpha-amylase and urease inhibitory activities of Melilotus indicus (Linn.) All. Pak. J. Pharm. Sci., 2014; 27(1): 57-61.

72) Golbabaei, S., Bazl, R., Golestanian, S., Nabati, F., Omrany, Z.B., Yousefi, B., Hajiaghaee, R., Rezazadeh, S., Amanlou, M. Urease inhibitory activities of $\beta$-boswellic acid derivatives. DARU. J. Pharm. Sci., 2013; 21(2): 1-6.

73) Jamil, M., Zubair, M., Rasool, N., Altaf, A.A., Rizwan, K., Hafeez, S., Bukhari, I.H., Langer, P. Synthesis, Characterization, Antibacterial and Urease Inhibition Studies of Some Novel Symmetrical $\quad N^{3}, N^{3}$-bis-(disubstituted)isophthalyl-bis-(thioureas). Asian. J. Chem. 2013; 25(10): 5328-5332.

74) Ullah, I., Khan, J.A., Adhikari, A., Khan, A., Hannan, P.A., Wadood, A., and Farooq, U. Bioassay- guided isolation of new urease inhibitory constituents from Monotheca buxifolia (Falc.) fruit and their molecular docking studies. Rec. Nat. Prod., 2016; 10(6): 744-749.

75) Ahmed, D., Mughal, Q.M., Younas, S., Ikram, M. Study of phenolic content and urease and alpha-amylase inhibitory activities of methanolic extract of Rumex acetosella roots and its sub-fractions in different solvents. Pak. J. Pharm. Sci., 2013; 26(3): 553-559.

76) Kaleem, W.A., Nisar, M., Qatyum, M., Haq, M.Z., Choudhary, M.I., Ercisli, S. Urease inhibitory potential of Zizyphus oxyphylla edgew. extracts and isolated compounds. Turkish Journal of Medical Sciences, 2013; 43: 497-500.

77) Zahid, H., Rizwani, G.H., Shareef, H., Ali, S.T. Antioxidant and urease inhibition activity of methanol extract of Hibiscus 
Indo Global Journal of Pharmaceutical Sciences, 2019; 9(1): 42-53

schizopetalus (Mast) Hook. Journal of Pharmacognosy and Phytochemistry, 2014; 2(6): 07-11.

78) Sokmen, B.B., Ugras, S., Sarikaya, H.Y., Ugras, H.I., Yanardag, R. Antibacterial, antiurease, and antioxidant activities of some arylidene barbiturates. Appl. Biochem. Biotechnol., 2013; 171: 2030-2039.

79) Bektas, H., Ceylan, S.U., Demirbas, N., Karaoglu, S.A., Sokmen, B.B. Antimicrobial and antiurease activities of newly synthesized morpholine derivatives containing an azole nucleus. Med. Chem. Res., 2012; 22: 3629-3639.

80) Lateef, M., Iqbal, L., Fatima, N., Siddiqui, K., Afza, N., Haq, M.Z. Ahmad, M. Evaluation of antioxidant and urease inhibition activities of roots of Glycyrrhiza glabra. Pak. J. Pharm. Sci., 2012; 25(1): 99-102.

81) Arfan, M., Ali, M., Ahmad, H., Anis, I., Khan, A., Choudhary, M.I., Shah, M.R. Urease inhibitors from Hypericum oblongifoliun Wall. J. Enzym. Inhib. Med. Ch., 2010; 25(2): 296-299.

82) Chen, Y., Liao, J., Chen, M., Huang, Q., Lu, Q. Gossypol: New class of urease inhibitors, molecular docking and inhibition assay. Journal of Chemical and Pharmaceutical Research, 2015; 7(1): 1015.

83) Berlicki, L., Bochno, M., Grabowiecka, A., Bialas, A., Kosikowska, P., Kafarski, P. $N$ - substituted aminomethanephosphonic and aminomethane- $P$-methylphosphinic acids as inhibitors of ureases. Amino. Acids, 2011; 42: 1937-1945.
84) Afza, N., Anis, I., Aslam, M., Hussain, A., Ssfder, M., Chaudhary, A.H., Iqbal, L., Lateef, M., Qayyum, A., Niaz, M. A Potent urease inhibitor $2-\{[(2-\{[(E)-(2-$ hydroxyphenyl)methylidene]amino\}ethyl)imino]methyl $\}$ phenolcopper (II) complex. Int. J. Curr. Pharm. Res., 2013; 5(2): 83-85.

85) Bekircan, O., Baltas, N., Mentese, E., Gultekin, E. Synthesis of new fluorine-containing 1,2,4-triazole-5-on derivatives with their anti-urease, anti-xanthine oxidase and antioxidant activities. Rev. Roum. Chim., 2016; 61(10): 733-746.

86) Shi, D.H., You, Z.L. Synthesis, characterization, and crystal structures of two schiff base zinc (II) complexes with urease inhibitory activities. Russian Journal of Coordination Chemistry, 2010; 36(7): 535-540.

87) Shahzad, S.A., Yar, M., Khan, Z.A., Khan, I.U., Naqvi, S.A.R., Mahmood, N., Khan, K.M. Microwave-assisted solvent free efficient synthesis of 1,3,4-oxadiazole-2 $(3 H)$-thiones and their potent in vitro urease inhibition activity. Eur. J. Chem., 2012; 3(2): 143-146.

88) Saeed, A., Mahmood, S., Rafiq, M., Ashraf, Z., Jabeen, F., Seo, S.Y. Iminothiazoline-sulfonamide hybrids as jack bean urease inhibitors; synthesis, kinetic mechanism and computational molecular modeling. Chem. Biol. Drug. Des., 2016; 87: 434-443.

89) Thadhani, V.M., Naaz, Q., Karunaratne, V., Choudhary, M.I. Mononuclear phenolic lichen compounds as potent urease inhibitors. Int. Symposium. Natural. Products., 2011; 3-8.

Indo Global Journal of Pharmaceutical Sciences( ISSN 2249 1023; CODEN- IGJPAI; NLM ID: 101610675) indexed and abstracted in CrossRef (DOI Enabling), UGC CARE Journal List, EMBASE(Elsevier), National Library of Medicine (NLM) Catalog, ResearchGate, Publons, CAS (ACS), Index Copernicus, Google Scholar and many more. For further details, visit http://iglobaljournal.com 